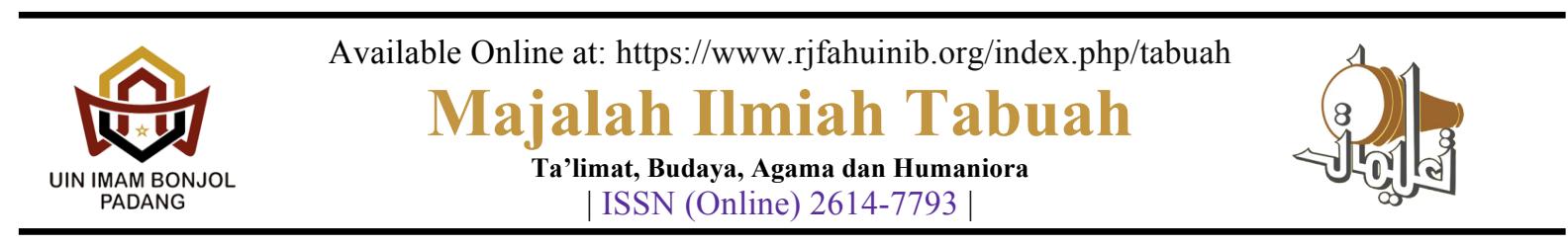

\title{
KONTENPLASI MASYARAKAT MUSLIM MELAYU PALEMBANG DALAM TANTANGAN EKONOMI GLOBAL
}

\author{
Raden Ayu Ritawati \\ Universitas Islam Negeri Raden Fatah Palembang \\ email: ra.ritawati_uin@radenfatah.ac.id \\ Raden Ayu Erika Septiana \\ Universitas Islam Negeri Raden Fatah Palembang \\ email: radenayuerikaseptiana_uin@radenfatah.ac.id
}

\begin{abstract}
Changes and acculturation process in Palembang Malay Muslim community render the Malay culture a ship sailing in the middle of a raging storm. This is because our development activities place too much emphasis on the material aspect which affects the Palembang Malay Muslim community's way of life, increasingly been eroded by globalization. Excessive material competition has produced apathetic societies. Their behaviours are reflected in the work ethics viewed through the norms and social structures. The purpose of this study is to find out how the global economy has the potential to blur Malay and pristine Muslim identities. The qualitative approach was chosen using the method of field research carried out to understand internal phenomena reflected through their views. The study found that the Palembang Malay Muslim communities lacked enthusiasm and work ethics. Indeed, the relationship between Malay and Islam attenuated the competitive spirit in the community to earn their livelihood. Religion is still considered an element of local culture, not as the guidelines which direct their lives. Indeed, religion's role in reducing anxiety and fear, thus encouraging humans to get involved in economic activities are not found in this study. This condition produces a generation deprived of values, fragile spiritually, susceptible, and apathetic, bereft of their cultures.
\end{abstract}

Keywords: Work ethic, competitiveness and the global economy

\section{Abstrak}

Seiring dengan kencangnya arus perubahan dan kuatnya proses akulturasi masyarakat muslim Melayu Palembang, kebudayaan Melayu laksana kapal yang berlayar ditengah badai. Hal ini dilandasi fakta bahwa pembangunan kita terlalu mengedepankan aspek material yang secara keseluruhan telah melahirkan ketidak seimbangan dalam pola prilaku masyarakat muslim Melayu Palembang yang semakin tergerus arus globalisasi 
ekonomi. Persaingan material yang berlebihan telah menghasilkan masyarakat yang anomi. Perwujudan dari cara orang Melayu Palembang bertingkah laku tercermin pula pada etos kerjanya yang secara kasar dapat dilihat dari struktur dan norma sosial masyarakatnya. Tujuan dari penelitian ini ingin mengetahui sejauh mana ekonomi global sangat berpotensi mengaburkan indentitas kemelayuan dan indentitas kemusliman yang murni. Pendekatan kualitatif dipilih menggunakan metode penelitian lapangan (field work) yang dilakukan berupayamemahami gejala-gejala sedemikian rupa berupa fenomena yang tidak bersifat eksternalyang terungkapkan lewat pandangan-pandangan mereka. Hasil dari penelitian ini menemukan kenyataannya bahwa semangat dan etos kerja justru kurang tercermin pada kebanyakan masyarakat muslim Melayu Palembang. Hubungan kemelayuan dan keislaman justru mengaburkan peran dan daya saing masyarakat dalam praktek hubungan sosial maupun dalam mencari nafkah. Agama masih dianggap sebagai unsur budaya lokal yang pekat dalam bentuk prilaku kebiasan adat ketradisionalan saja, bukan sebagai pijakan, arahan dan pandangan hidup. Sejatinya agama berfungsi untuk mendorong manusia untuk terlibat dalam peran-peran dan tingkah laku ekonomi, karena agama dapat mengurangi rasa cemas dan takut tidak terlalu ditemukan dalam penelitian ini.Dimana efek lanjutan dari kondisi ini memunculkan generasi yang tercerabut dari nilai-nilai, generasi yang rapuh dari aspek spiritual, mudah terpengaruh, tidak mudah perduli dan kehilangan pijakan budaya.

Kata Kunci: Etos Kerja, Daya Saing dan Ekonomi Global

\section{PENDAHULUAN}

Masyarakat sebagaimana juga masyarakat suku bangsa lain di Nusantara, Malaysia, Singapura dan Berunai Darussalam, mengakui diri sebagai orang Melayu. Bagi masyarakat Palembang, sebutan "orang Melayu" bukan berarti sebagai pembeda dari suku bangsa atau etnis tertentu. Menjadi Melayu bagi orang Palembang bukan sekedar sebutan, tetapi juga warisan. Sebagai kebanggaan dari peradaban yang pernah sangat berjaya sebagai cikal bakal dari budaya Melayu itu sendiri yaitu kerajaan Sriwijaya.

Sejarah mencatat, perjalanan bangsa Melayu dalam ihwal berkerajaan, mulai dari Bukit Siguntang sampai ke kawasan Tanah Semenanjung, Kepulauan Riau dan Riau, serta kawasan lain, telah membuktikan bahwa bangsa ini adalah bangsa yang mapan dan piawai di tengah terpaan kekuatan bangsa lain yang ingin menguasainya.

Merujuk sejarahnya sejak abad ke 16, tepatnya tahun 1511 Portugis masuk ke Indonesia, kemudian disusul oleh VOC Belanda pada tahun 1596 di Banten, hubungan kerajaan-kerajaan di wilayah Indonesia dengan Belanda pada mulanya mempunyai status yang sederajat. Namun pada abad ke 18 terjadi pergeseran, kedudukan kerajaankerajaan berada di bawah penguasa Kolonial Belanda ${ }^{1}$, demikian juga yang terjadi di Kesultanan Palembang.Hubungan birokrasi tradisional dengan pemerintah kolonial Belanda itu membawa akibatdikenalnya sistem kolonial yang berupa monopoli dan sistem ekonomi kapitalisme di

\footnotetext{
${ }^{1}$ J.C. Van Leur. Perdagangan dan Masyarakat Indonesia : Esai-esai Tentang Sejarah Sosial dan Ekonomi Asia. 2015. Yogyakarta : Penerbit Ombak. h. 15
} 
seluruh Nusantara ${ }^{2}$ yang seterusnya menjadi akar dari kapitalisme birokrasi di Indonesia.

Dampak yang paling nyata dalam sistem kesetiaan hubungan tersebut tercermin pada sejarah globalisasi perekonomian dan pendapatan masyarakat Melayu Palembang yang sejak zaman kesultanan berasal dari perdagangan dan tradisi pertanian yang menghasilkan komoditas ekspor seperti kopi dan karet, disamping bertanam padi dan palawija untuk keperluan sehari-hari. Dari hasil pertanian tersebut mereka dapat hidup makmur. Sejak dahulu Sultan dan pusat pemerintahan dapat memetik hasil perdaganan kopi dan karet dalam kurun waktu yang lama ${ }^{3}$. Namun, karena kebijakan globalisasi ekonomi pula setelah tanahtanah orang Melayu Palembang dijadikan perkebunan, timbul perubahan-perubahan yang tidak saja menyangkut sistem perekonomian masyarakat Melayu tetapi juga menyangkut kepentingan Sultan (pemerintahan). Perubahan ini telah membentuk dampak psikologis yang merugikan orang Melayu asli Palembang. Mereka menjadi tidak terbiasa membuka hutan baru untuk mengelolanya menjadi tanah pertanian kopi atau karet. Mereka hanya menanti tanah yang telah diolah dan hanya menanti musim panen ${ }^{4}$.

Masihuntung, jika nasib petani Melayu asli Palembang di masa lalu relatif mampu ke luar dari perangkap sistem tanam paksa, tidak seperti yang dialami oleh saudara-saudara mereka di Jawa, misalnya. Lagi pula, konsep petani Melayu Palembang agaknya memang merupakan suatu jenis yang khas dari tipe rational peasant (petani rasional) seperti yang diidentifikasi oleh

\footnotetext{
${ }^{2}$ Baca Wiliam Masden. Sejarah Sumatera. 2013. Jakarta: Penerbit Komunitas Bambu. h. 239

${ }^{3}$ Lihat Edwin M. Loeb. Sumatera Sejarah dan Masyarakatnya. 2013. Jakarta: Penerbit Ombak.

${ }^{4}$ Mestika Zen. Ibid.2003. h. 57.
}

Popki $^{5}$. Khas, karena petani Melayu Palembang pada dasarnya adalah individu-individu yang sebelah kakinya berada dalam sawah-ladang-kebundan yang sebelah lagi dalam pasar. Maka menurut Mestika, definisi konvensional tentang petani sebagai "tukang cocok tanam yang senantiasa terbenam untuk mencukupi kebutuhan sendiri (selfsufficiency), karena alasan mentaliteit mereka yang statik tak mau berkembang, sebagaimana dikatakan Boeke, sepertinya kurang mengena bagi sebagian besar masyarakat Melayu Palembang.

Sebagaimana masyarakat Melayu pribumi lainnya yang berada di semua bagian Pulau Sumatera dan Kalimantan, masyarakat Palembang mengakuibahwa sebagaiorang Melayu berarti juga mengaku sebagai bagian indentitas kolektif atau milik bersama sebagai bagian dari suku bangsa Melayu Nusantara yang merasa memiliki banyak ragam dan ciri kesamaan, tidak cuma bahasa, budaya, adat istiadat tetapi juga prilaku dan pola pikir atau etos kerja. Menurut Tabrani, ciri-ciri kepribadian orang Melayu secara keseluruhan terjelma dalam cara orang Melayu berfikir, bersikap, dan bertingkah laku ${ }^{6}$.

Perwujudan dari cara orang Melayu bertingkah laku tercermin pula pada etos kerjanya. Sementara gambaran nyata dari etos kerja secara kasar dapat dilihat dari struktur dan norma sosial masyarakat itu sendiri. Dengan cara lain Abdullah mengatakan bahwa etos kerja merupakan landasan bagi kehidupan manusia, sehingga ia juga berhadapan dengan aspek evaluatif yang bersifat menilai dalam kehidupan

\footnotetext{
${ }^{5}$ Baca Samuel LPopkins dalam Petani Rasional. 1986. Jakarta: Penerbit Yayasan Padamu Negeri.

6 Tabrani dalam Koentjaraningrat. Masyarakat Melayu dan Budaya Melayu dalam Perubahan (Kumpulan Naskah Esai-esai penelitian). 2007. Yogyakarta: Balai Kajian dan Pengembangan Budaya Melayu. h. 453.
} 
masyarakat ${ }^{7}$. Sementara Geetz berpendapat bahwa etos seseorang dapat dilihat dari gaya, ciri, kualitas kehidupan, dan akhlak, serta rona estetikanya. Oleh karena itu etos tidak dapat dipisahkan dan bahkan merupakan bagian dari sistem kebudayaan dan perilaku ekonomi. Sebagai watak dasar suatu masyarakat, etos berakar dalam kebudayaan masyarakat itu sendiri. Kebudayaan sebagai suatu sistem gagasan yang dimiliki suatu masyarakat dari proses belajar, adalah induk etos itu.

Kepribadian orang Melayu asli Palembang sebagaimana umumnya suku bangsa Melayu lainnya secara umum dibentuk oleh tradisi adat istiadat Melayu serta ajaran Islam. Inilah yang dikatakan banyak ahli sejarah Melayu sebagai "kepribadian kebudayaan" (personal of culure atau culture personality $)^{8}$. Sehubungan dengan itu, kemelayuan juga dapat dipandang sebagai suatu pola kebudayaan yang muncul atau mewujud dalam realitas karena adanya pola-pola kepribadian tertentu pada sejumlah individu atau orang yang dibesarkan dalam bingkai budaya.

Oleh karena itu penting kiranya bagi kita semua untuk lebih memahami hakekat dari kemelayuan itu sendiri sebagai bagian dari budaya daerah, sebagaimana pendapat dari Ahmad Dahlan yang mengatakan bahwa memahami kebudayaan merupakan suatu yang amat penting dalam membaca dan memahami masyarakat, menganalisis perbedaan ${ }^{9}$. Ketika sebuah hakikat tamadun Melayu ingin diangkat, serta merta mengikatkan kita kepada identitas keislamannya yang sangat

\footnotetext{
${ }^{7}$ Taufik Abdullah, (ed.). Agama, Etos Kerja dan Perkembangan Ekonomi.1988.Jakarta: LP3ES. h.3

8 Lihat Heidi Shri Ahimsa-Putra. Masyarakat Melayu dan Budaya Melayu dalam Perubahan. 2007. Balai Kajian dan Pengembangan Budaya Melayu, Riau. h. 12-14. ${ }^{9}$ Lihat Ahmad Dahlan, PhD. Sejarah Melayu. 2014. PT Gramedia, Jakarta. h. 17
}

kentara, karena menjadi Melayu adalah berarti menjadi Islam ${ }^{10}$ (muslim).

Dengan pembatasan Melayu yang telah mengerucut sebagai suku bangsa atau etnis, orang yang tetap bersetia sebagai Melayu menjadi berbeda misalnya dengan suku bangsa atau etnis Batak, Aceh, Minang, Banjar, Dayak, Sunda, Jawa, Madura, Bugis, Ambon dan seterusnya yang telah mendefinisikan diri mereka sebagai suku bangsa atau etnis selain Melayu.

Catatan penting yang perlu dicermati bahwa adanya proses perubahan filsafat Melayu yang pada dasarnya bertahap dari metafisis menuju ke teologis dan akhir-akhir ini menuju rasionalis. Selain itu, baik Koentjaranigrat, Thabrani maupun Imron berkomentar bahwa orang Melayu yang baik selalu merendahkan diri dan tidak menonjolkan dirinya, tidak mau memaksakan kemauannya jika kemauannya itu bertentangan dengan kemauan orang lain. Orang Melayu senantiasa bersahaja dan bersedia kompromi.

Meski begitu pada kenyataannya saat ini kita semua menghendaki perubahan. Melayu sekarang tidak harus sama dengan Melayu lima abad yang lalu. Dalam era teknologi tinggi, manusia Melayu perlu menyadari bahwa etos Melayu harus lahir dalam era positivis dengan pilar rasionalisten pragmatis.

Oleh karena itu, seiring dengan kencangnya arus perubahan dan kuatnya proses akulturasi ditengah masyarakat muslim (Islam) Melayu itu sendiri sebagaimana muslim Melayu asli Palembang, kebudayaan Melayu laksana kapal yang berlayar ditengah badai. Hal ini dilandasi fakta bahwa pembangunan kita terlalu mengedepankan aspek material. Dalam beberapa dekade ini pembangunan secara keseluruhan telah melahirkan ketidak seimbangan dalam pola prilaku masyarakat, termasuk pula masyarakat muslim Melayu asli Palembang yang 
semakin tergerus arus globalisasi ekonomi yang semakin membudaya. Persaingan material yang berlebihan telah menghasilkan masyarakat yang anomi. Capaian-capaian, khususnya bidang ekonomi, ternyata telah mengubah manusia menjadi makhlukmakhluk bebas nilai, relatif kejam, dan saling memandang hubungan sosial atau bahkan hubungan antar negara dengan pertimbangan untung rugi atau kepentingan ekonomi semata. Efek lanjutan dari kondisi ini menurut Thabrani memunculkan generasi yang tercerabut dari nilai-nilai, generasi yang rapuh dari aspek spiritual, mudah stress, mau enak sendiri dan kehilangan pijakan $^{11}$.

Selain itu adanya fakta bahwa globalisasi dibidang ekonomi atau ekonomi global sangat berpotensi mengaburkan indentitas,termasuk indentitas kemelayuan dan indentitas kemusliman yang murni. Hal ini bisa dimaklumi, karena ekonomi global bisa membuat siapapun atau negara manapun dapat memasuki "pintu" pihak lain tanpa sekat. Semua saling membaur dan mempengaruhi secara mendalam. Dalam kebudayaan, perubahan dan pembaharuan (globalisasi) merupakan keharusan, karena perjalanan zaman dan kehidupan manusia selalu berkembang.

\section{Teori Etos Kerja}

Menurut KBBI secara etimologi istilah etos berarti "tempat hidup" ${ }^{12}$. Mula-mula tempat hidup dimaknai sebagai adat istiadat atau kebiasaan. Sejalan dengan waktu, kata etos berevolusi dan berubah makna menjadi semakin kompleks. dari kata yang sama muncul pula istilah ethikos yang berarti "teori kehidupan" yang kemudian menjadi etika. Menurut Dictionary mendefenisikan etos sebagai guilding beliefs of a person, group or institution. etos adalah keyakinan yang menuntun

\footnotetext{
${ }^{11}$ Thabrani (2007), h. 457.

${ }^{12}$ Poerwadarminto WJS, 1987, Kamus Umum Besar Bahasa Indonesia,_Jakarta, Balai Pustaka,
}

seseorang, kelompok atau suatu institusi.

Etos dibentuk oleh berbagai kebiasaan, pengaruh, budaya serta sistem nilai yang diyakininya. Dari kata etos ini dikenal pula kata etika yang hamper mendekati pada pengertian akhlak atau nilai-nilai yang berkaitan dengan baik buruk moral sehingga dalam etos tersebut terkandung gairah atau semangat yang amat kuat untuk mengerjakan sesuati secara optimal lebih baik dan bahkan berupaya untuk mencapai kualitas kerja yang sesempurna mungkin.

$$
\text { Menurut Gregory } 13 \text { sejarah }
$$
membuktikan negara yang dewasa ini menjadi negara maju, dan terus berpacu dengan teknologi/informasi tinggi pada dasarnya dimulai dengan suatu etos kerja yang sangat kuat untuk berhasil. Maka tidak dapat diabaikan etos kerja merupakan bagian yang patut menjadi perhatian dalam keberhasilan suatu bangsa, perusahaan besar dan terkenal telah membuktikan bahwa etos kerja yang militan menjadi salah satu dampak keberhasilan perusahaannya. Etos kerja seseorang erat kaitannya dengan kepribadian, perilaku, dan karakternya. Setiap orang memiliki internal being yang merumuskan siapa dia. Selanjutnya internal being menetapkan respon, atau reaksi terhadap tuntutan external. Respon internal being terhadap tuntutan external dunia kerja menetapkan etos kerja seseorang ${ }^{14}$.

Etos juga berarti karakter, cara hidup, kebiasaan seseorang, motivasi atau tujuan moral seseorang serta pandangan dunia mereka, yakni gambaran, cara bertindak ataupun gagasan yang paling komprehensif mengenai tatanan. Dengan kata lain etos adalah aspek evaluatif sebagai sikap mendasar terhadap diri dan dunia mereka yang direfleksikan dalam kehidupannya.

Menurut Geertz,etos adalah sikap yang mendasar terhadap diri dan dunia

\footnotetext{
${ }^{13}$ Gregory (2003)

${ }^{14}$ Siregar(2000). h. 25
} 
yang dipancarkan hidup. Sikap disini digambarkan sebagai prinsip masingmasing individu yang sudah menjadi keyakinannya dalam mengambil keputusan $^{15}$.

Menurut kamus Webster, etos didefinisikan sebagai keyakinan yang berfungsi sebagai panduan tingkah laku bagi seseorang, sekelompok, atau sebuah institusi (guiding beliefs of a person, group or institution). Menurut Usman Pelly, etos kerja adalah sikap yang muncul atas kehendak dan kesadaran sendiri yang didasari oleh sistem orientasi nilai budaya terhadap kerja. Dapat dilihat dari pernyataan di muka bahwa etos kerja mempunyai dasar dari nilai budaya, yang mana dari nilai budaya itulah yang membentuk etos kerja masing-masing pribadi.

Bila ditelusuri lebih dalam, etos kerja adalah respon yang dilakukan oleh seseorang, kelompok, atau masyarakat terhadap kehidupan sesuai dengan keyakinannya masing-masing. Setiap keyakinan mempunyai sistem nilai dan setiap orang yang menerima keyakinan tertentu berusaha untuk bertindak sesuai dengan keyakinannya. Bila pengertian etos kerja re-definisikan, etos kerja adalah respon yang unik dari seseorang atau kelompok atau masyarakat terhadap kehidupan; respon atau tindakan yang muncul dari keyakinan yang diterima dan respon itu menjadi kebiasaan atau karakter pada diri seseorang atau kelompok atau masyarakat.Dengan kata lain, etika kerja merupakan produk dari sistem kepercayaan yang diterima seseorang atau kelompok atau masyarakat.

Etika tentu bukan hanya dimiliki bangsa tertentu. Masyarakat dan bangsa apapun mempunyai etika; ini merupakan nilai-nilai universal. Nilainilai etika yang dikaitkan dengan etos kerja seperti rajin, bekerja, keras, berdisplin tinggi, menahan diri, ulet, tekun dan nilai-nilai etika lainnya bisa juga ditemukan pada masyarakat dan bangsa lain. Kerajinan, gotong royong, saling membantu, bersikap sopan misalnya masih ditemukan dalam masyarakat kita. Perbedaannya adalah bahwa pada bangsa tertentu nilai-nilai etis tertentu menonjol sedangkan pada bangsa lain tidak.

\section{Teori Etos Kerja Islami}

Menurut Izzuddin Al-Khatib AtTamimi memberikan batasan tentang etika kerja atau etos kerja dalam Islam adalah bekerja dengan jujur dan tanggung jawab, dapat dipercaya, selalu menepati janji, toleransi terhadap sesama, selalu menjaga mulut dari rasa iri dengki terhadap orang lain dan menghindari dari suka menfitnah ${ }^{16}$. Menurut Abdullah ${ }^{17}$, ada konsep innerwordly asceticism yang mempengaruhi orang bekerja keras dan merupakan dasar etos atau semangat yang mempengaruhi sikap utama manusia terhadap diri mereka sendiri dan terhadap dunia sekeliling. Etos kerja dalam mengejar kepentingan ekonomi dalam ajaran Islam bagaimanapun pentingnya tidak lebih hanya merupakan satu bagian dari keseluruhan aspek kehidupan manusia, sekalipun memang diakui sebagai bagian pokok dan amat berpengaruh ${ }^{18}$. Menurut Dr. Musa Asyeeari, etos kerja yang Islami sejatinya rajutan nilai-nilai kekhalifahan dan kehambaan yang membentuk kepribadian muslim ${ }^{19}$. Nilai-nilai kekhalifahan bermuatan kreatif, produktif, inovatif, berdasarkan pengetahuan konseptual, sedangkan nilai-nilai kehambaan bermuatan moral,

${ }^{16}$ Izzuddin Al-Khatib At-Tamimi, Nilai Kerja dalam Islam, Jakarta: CV. Mantiq, 1992, h. 79

${ }^{17}$ Ibid. Abdullah (2003). xv-xvi h. 13.

${ }^{18}$ Musa Asy'arie Islam.Etos Kerja dan Pemberdayaan Ekonomi Ummat, Yogyakarta: Lesfi, 1997, cet. Ke-1, hl.14

${ }^{19}$ Musa Asy'arie Islam.Etos Kerja dan Pemberdayaan Ekonomi Ummat, Yogyakarta: Lesfi, 1997, cet. Ke-1, hl.14

15 Ibid (1982) h. 23 
taat dan patuh pada hukum agama dan masyarakat $^{20}$.

Etos kerja merupakan hal yang berkaitan dengan nilai kejiwaan seseorang, hendaknya setiap pribadi muslim harus mengisinya dengan kebiasaan-kebiasaan positif, dan menghasilkan pekerjaan yang terbaik, sehingga nilai-nilai Islam yang diyakininya dapat diwujudkan. Etos juga menunjukkan sikap dan harapan seseorang. Secara hakiki, bekerja bagi seorang muslim adalah ibadah, bukti pengabdian dan rasa syukurnya untuk mengolah dan memenuhi panggilan Ilahi agar mampu menjadi yang terbaik karena mereka sadar bahwa bumi diciptakan sebagai ujian bagi mereka yang memiliki etos yang terbaik ${ }^{21}$.

Sebagai agama yang bertujuan mengantarkan hidup manusiakepada kesejahteraan dunia dan akhirat, lahirdan batin, Polahidup Islami tersebut dengan jelas dalam Al-Qurean dan terurai dengansempurna dalam sunnah Rasulullah s.a.w ${ }^{22}$.Dengan demikian, seorang muslim dituntut untuk senantiasa meningkatkan kualitas hidup sehingga eksistensinya bermakna dan bermanfaat di hadapan Allah SWT, yang pada akhirnya mencapai derajat Al-hayat Al-thoyyibah (hidup yang diliputi kebaikan). Untuk mencapai tersebut maka setiap muslim diwajibkan beribadah, bekerja, berkarya berinovasi atau dengan kata lain beramal saleh ${ }^{23}$. Sebagaimana firman Allah SWT yaitu:

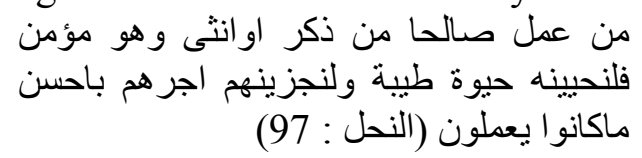

Artinya:

20 Hidayatullah. Islam Reformis,

Dinamika Intelektual dan Gerakan, Jakarta: Rajawali Press. h. 70

${ }^{21}$ Koentowijoyo. 2001. Muslim Tanpa Mesjid: Esai-Esai Agama, Budaya, dan Politik dalam Bingkai Strukturalisme Transendental. Bandung: Mizan

${ }^{22}$ Hamzah Ya'qub, “Etos Kerja

Islami”,1992. Jakarta: CV Pedoman Ilmu Jaya,, h. 6

${ }^{23}$ Toto Tasmara, Etos Kerja Muslim, Jakarta: Labmend, 1991, Cet. Ke-1, hl. 12
"Barang siapa yang beriman, maka sesungguhnya akan kami berikan kepadanya kehidupan yang baik, dan sesungguhnya akan kami beri balasan kepada mereka dengan pahala yang lebih baik dari apa yang telah mereka kerjakan”. (QS An-Nahl: 97).

Taqwa merupakan dasar utama kerja, apapun bentuk dan jenis pekerjaan, maka taqwa merupakan petunjuknya. Memisahkan antara taqwa dengan iman berarti mengucilkan Islam dan aspek kehidupan dan membiarkan kerja berjalan pada wilayah kemashlahatannya sendiri. Bukan kaitannya dalam pembangunan individu, kepatuhan kepada Allah SWT serta pengembangan umat manusia.

Perlu kiranya dijelaskan disini bahwa kerja mempunyai etika yang harus selalu diikut sertakan didalamnya, oleh karenanya kerja merupakan bukti adanya iman dan barometer bagi pahala dan siksa. Hendaknya setiap pekerjaan disampIng mempunyai tujuan akhir berupa upah atau imbalan, namun harus mempunyai tujuan utama, yaitu memperoleh keridhaan Allah SWT. Prinsip inilah yang harus dipegang teguh oleh umat Islam sehingga hasil pekerjaan mereka bermutu dan monumental sepanjang zaman.

\section{PEMBAHASAN}

\section{Keberagaman EtnisKelompok Tenaga Kerja di Palembang}

Tidak dapat dipungkiri bahwa keberadaan masyarakat pekerja Melayu Palembang pada saat ini telah mulai memudar bersama semakin terkikisnya kesadaran trasedental mereka terhadap jati diri dan kesukuannya. Peran masyarakat pekerjaMelayu Palembang secara golongan mungkin masih banyak memiliki andil dan berjaya dalam melahirkan peradaban di Palembang. Namun, secara individu, peran 
masyarakat pekerja Melayu agaknya perlu dilacak dan dipertanyakan.

Bagaimana pun pada kenyataannya, adanya variasi pemahaman tentang identitas pekerja Melayu Palembang dewasa ini menjadi kurang penting bilamana dibandingkan dengan semangat kebangkitan kesadaran Melayu itu sendiri. Karena membangkitkan kesadaran ini tentu berkaitan dengan banyak faktor. Paling menonjol diantaranya adalah adanya keprihatinan Melayu Palembang karena merasa tertekan atau merasa dikepinggirkan oleh kekuatan yang lebih besar, tapi seringkali abstrakentah itu namanya "globalisasi" dan "birokrasi negara" atau "pembangunan" atau persaingan bisnis multinasional dan lain-lain.

Menyimak kembali akar budayanya, sejak dasawarsa kedua abad ke-20 Palembang merupakan salah satu daerah di Pulau Sumatera yang memiliki potensi ekonomi paling besar setelah Sumatera Timur. Pemerintah kolonial menjadikan daerah Palembang sebagai tempat mengeruk keuntungan (wingewest) paling penting di luar Jawa. Pengusaha-pengusaha swasta Barat, pekerja bebas, kuli kontrak, kaum profesional dan pedagang dari berbagai kelompok etnis juga menjadikan Palembang sebagai tempat mengadu nasib. Berbagai cara mereka mereka upayakan untuk membuka dan mengeksploitasi daerah Palembang.

Dalam beberapa batasan tertentu Palembang merupakan "daerah tanaman" (cultuurgebied) dan tempat berhimpun para kuli kontrak dari Jawa. Investasi yang ditanam sebagian besar dicurahkan untuk kegiatan eksploitasi industri minyak bumi. Para pekerja yang didatangkan dari Jawa disebar di berberapa tempat dan dipekerjakan perusahaan-perusahaan perkebunan dan pertambangan atau bekerja pada jenis lapangan kerja lain. Arus perpindahan tersebut seiring dengan meningkatnya kebutuhan perusahaan swasta, proyek- proyek pemerintah, dan berbagai jenis lapangan kerja lain akan tenaga kerja.

Menurut penelitian Jeroen Peeters, Wiliam Masden maupum Andaya, etnis Cina yang menjalankan usaha sendiri atau bekerja di daerah Palembang tampil cukup dominan. Namun mereka bukan kelas buruh dalam arti "kuli" kasar seperti banyak ditemukan di banyak kawasan di luar Jawa umumnya serta Sumatera Timur dan Bangka Belitung khususnya. Sebagian besar mereka mampu mengintegrasikan diri bahkan melebur kedalam masyarakat setempat. Sebagian etnis Cina adalah pendatang-pendatang bebas yang mampu dengan cepat menguasai sektor-sektor ekonomi tertentu, terutama dibidang perdagangan. Diantaranya bahkan muncul sebagai kelompok konglomerat yang mendominasi perekonomian Palembang.

Sebagian besar orang dari Jawa di Palembang merupakan pekerja dengan status "buruh kontrak" perusahaanperusahaan perkebunan dan tambang batu bara. Mereka hampir dapat ditemukan di setiap jenis lapangan kerja yang tidak membutuhkan ketrampilan khusus, atau di bidang pekerjaan yang mesyaratkan keahlian cukup tinggi. Mereka yang tidak mempunyai ketrampilan biasanya bekerja sebagai pembantu rumah tangga (tukang masak, tukang kebun dan tukang cuci) keluarga kaya Belanda, Cina dan bangsawan kaya Palembang. Ada juga yang bekerja sebagai pekerja upah lepas di perusahaan-perusahaan perkebunan dan manufaktur. Tidak sedikit di antara mereka mencari nafkah sebagai kuli angkut di stasiun kereta api, kuli pelabuhan, atau bekerja sebagai pegawai teknis dalam birokrasi pemerintahan.

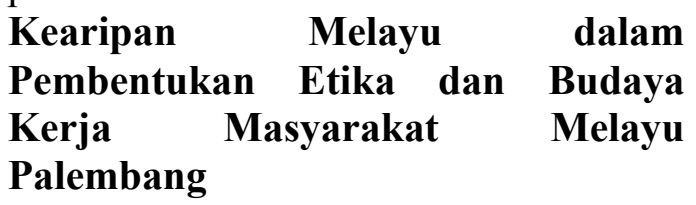


Dalam kehidupan orang Melayu, etika atau budaya kerja mereka telah diwariskan oleh orang tuanya secara turun temurun. Masyarakat Melayu Palembang dulunya memiliki budaya kerja yang disebut "semangat kerja" yang tinggi, semangat yang mampu mangangkat hakikat dan martabat kaumnya "untuk duduk sama rendah tegak sama tinggi" dengan masyarakat dan bangsa lain. Sedangkan, budaya kerja masyarakat Melayu Palembang yang lazim disebut dengan "pedoman kerja Melayu", diakui oleh banyak ahli, karena hal ini sangat ideal dengan budaya kerja yang universal, terutama didunia Islam.

Orang-orang tua Melayu Palembang dulu mengatakan "berat tulang ringanlah perut", maksudnya, orang yang malas bekerja hidupnya akan melarat. Sebaliknya, "ringan tulang beratlah perut" yang bearti barang siapa yang bekerja keras, hidupnya pasti akan tenang dan berkecukupan.

Didalam untaian ungkapan masyarakat Melayu dikatakan:

\section{Kalau hendak menjadi orang \\ Rajin-rajin membanting tulang \\ Manfaatkan umur sebelum petang}

Pahit dan getir usah dipantang

Kalau hendak menjadi manusia

Ringankan tulang habiskan daya

Kerja yang berat usah dikira

Pahit dan manis supaya dirasa

Ungkapan diatas, dahulunya disebarluaskan ketengah-tengah masyarakat Melayu Palembang dijabarkan, diuraikan, dan dihayati secara keseluruhan oleh anggota masyarakat Melayu Palembang. Penyebarluasan ungkapan tersebut melalui beberapa cara seperti didalam cerita-cerita, nasihat, upacara adat, nyanyian rakyat, pantun nasihat dan petuah, dsb.

Dalam adat Melayu Palembang, banyak menyerap nilai-nilai agama Islam. Menurut Islam Melayu, orang yang tidak bekerja, apalagi yang sengaja tidak mau bekerja, dianggap melalaikan kewajiban, melupakan tanggung jawab, menafikan ajaran agama dan tuntunan adat-istiadat serta mengabaikan tunjuk ajar yang banyak memberi petuah amanah tentang budaya kerja.

Orang tua-tua Melayu Palembang dulu juga mengingatkan, bahwa dalam mencari peluang kerja, jangan memilihmilih. Maksudnya jangan mencari kerja yang senang, dan tidak mau berkerja keras, itu bukanlah sikap orang Melayu Palembang yang ingin maju. Kerja yang perlu dipilih adalah kerja jangan "menyalah", maksudnya jangan menyimpang dari ajaran agama dan adat-istiadat. Sesuai dengan pepatah petitih umumnya yang diyakini masyarakat Melayu yang mengatakan "kalau kerja sudah menyalah, dunia akkhirat aib terdedah".

Keutamaan kerja masyarakat Melayu Palembang, tercermin pula dalam memilih menantu atau jodoh. Orang yang belum bekerja, lazimnya dianggap belum mampu "menghidupkan anak bininya". Orang seperti ini tidak akan dipilih untuk menjadi menantu atau pun jodoh anaknya. Beberapa pernyataan diatas memberikan petunjuk bahwa orang Melayu Palembang telah menanamkan budaya kerja dalam kehidupan masyarakatnya. Bahkan pihak orang tua perempuan selalu meminta mahar yang sangat tinggi bagi jodoh anak perempuannya. Sehingga ada ungkapan ekstrim bagi masyarakat suku lain di luar masyarakat Melayu Palembang bahwa "Hati-hatilah bemain-main dengan anak gadis orang Melayu Palembang bila tidak ada harta sekapal (seperahu), janganlah coba-coba melamar bila tidak ingin ditenggelamkan di sungai", Hal ini diyakini bahwa para orang tua Melayu Palembang sangat ketat menjaga anak perempuannya. Bagi para orang tua Melayu Palembang, menantunya haruslahseorang yang bertanggung jawab, bekerja dan berpenghasilan 
layak demi mencukupi istri dan anaknya kelak, selain itu juga mampu menjadi kebanggaan bagi keluarganya.

Para ahli antropologi dan sosiologi yang telah melakukan kajian terhadap budaya kerja orang Melayu, yang kemudian menarik suatu kesimpulan bahwa orang Melayu "pemalas" dalam bekerja, baik kerja tani, buruh, pegawai, dan dunia perdagangan. Itulah kesimpulan yang telah diambil oleh Cortesau, (1940), Raflfles (1935), dan Wheeler (1928). Sedangkan G.D. Ness dalam bukunya yang berjudul Bureaucracy and Rulal Development in Malaysia (1967) yang mengatakan orang Melayu dibandingkan dengan orang Cina kurang berorientasi pada hasil dan kesuksesan hidup.

\section{Peran Kearipan Melayu, Nilai-nilai Agama dan Daya Saing Tenaga Kerja Melayu Palembang dalam Era Ekonomi Global}

Globalisasi sebagai sebuah gejala merupakan proses tersebarnya nilainilai dan budaya tertentu keseluruh dunia (sehingga menjadi budaya dunia atau world culture) telah terlihat semenjak lama. Namun, perkembangan globalisasi kebudayaan secara intensif terjadi pada awal abad ke-20 dengan berkembangnya teknologi komunikasi. Kontak melalui media menggantikan kontak fisik sebagai sarana utama komunikasi antarbangsa. Perubahan tersebut menjadikan komunikasi antarbangsa lebih mudah dilakukan, hal ini menyebabkan semakin cepatnya perkembangan globalisasi kebudayaan.

Sementara itu globalisasi menarik negara-negara ke dalam dunia yang kompetitif. Sebuah perjalanan menuju kolaborasi baru dan kesatuan, telah mengubah dunia menjadi desa global. Jarak dan isolasi telah berkurang. Globalisasi

mengintegrasikan perdagangan, teknologi, investasi, dan faktor-faktor produksi seperti tenaga kerja dan modal. Globalisasi merupakan subjek yang biasa diperdebatkan. Sebagian orang berpendapat bahwa globalisasi memiliki banyak efek buruk pada masyarakat, terdapat orang lain yang merasa justru sebaliknya. Beberapa berpendapat bahwa globalisasi telah membuat hidup sangat mudah dan nyaman.

Dalam kenyataannya dewasa ini, perubahan lingkungan strategis bagi pembentukan tenaga kerja Melayu Palembang memang perlu dibenahi, diperbaiki dan dipacu pada proses menghadapi era pasar bebas (ekonomi global), dimana menurut hasil wawancara dan pengambilan pernyataan di lapangan, umumnya mereka mengeluhkan pada buruknya peluang penyerapan tenaga kerja-tenaga kerja Melayu Palembang didunia pekerjaan. Lingkungan strategik hendaknya mampu memberi motivasi dan daya dorong yang optimal bagi pembentukan jati diri para masyarakat pekerja Melayu Palembang dalam meraih dan mendapatkan pekerjaan sesuai dengan pendidikan dan kemampuannya.

Pada kenyataannya sekarang ini, arus globalisasi sudah semakin menenggelamkan posisi tawar tenaga kerja Melayu Palembang di dunia pekerjaan. Hal ini kadang terjadi justru bukan semata-mata karena tenaga kerja Melayu Palembang berkualifikasi rendah, namun karena kondisi lingkungan yang terkadang sangat kurang mendukung tenaga kerja-tenaga kerja Melayu Palembang untuk lebih membuka diri dan membuktikan kemandiriannya. Banyaknya berhimpun tenaga kerja asing di kota Palembang dengan tingkat kompetisi dan kualifikasi yang sangat memadai, merupakan tantangan yang tidak boleh dilihat sebagai peluang untuk berkompetisi lebih kompetitif. Justru sebaliknya, kehadirian tenaga kerja asing maupun domestik ke kota Palembang, paling tidak sudah mampu melahap jatah kesempatan kerja bagi tenaga kerja Melayu Palembang.

Selain dampak terhadap perekonomian globalisasi juga 
berdampak terhadap sosial budaya masyarakat Melayu Palembang (kearifan lokal Melayu). Dewasa ini globalisasi telah mendorong terjadinya pergeseran atau perubahan terhadap sistem atau aturan yang tumbuh dan berkembang dalam masyarakat Melayu Palembang secara menyeluruh. Perkembangan teknologi memiliki andil yang sangat besar dalam menggiring tenaga kerja Melayu Palembang kearah dekandensi moral Melayu yang merupakan warisan budaya dan cerminan adat dan norma agama. Rusaknya mental dan akhlak sebagian besar tenaga kerja Melayu Palembang sekarang ini diakibatkan oleh gaya hidup yang kapitalis,materialistik dan individualistik. Selain itu menjamurnya situs-situs internet yang menyajikan tayangan yang tidak mendidik dan bijak yang bisa diakses secara bebas semakin menambah deretan kehancuran budaya dan adat Melayu itu sendiri.

Hal tersebut menyebabkan kearifan-kearifan yang berlaku dalam masyarakat Melayu Palembang mulai terkikis. Masyarakat Melayu Palembang memiliki adat yang dikenal sebagai ada kedaerahan (kearifan lokal) yang merupakan simbol kedaerahan dan kebangsaan, namun saat ini, hampir tidak ada lagi makna yang berarti di era globalisasi ini.

Demikian juga pada masyarakat pekerja Melayu Palembang, etos kerja masyarakat Melayu Palembang cenderung pada tingkatan statis dan menunggu, kalau tidak ingin dikatakan pemalas, tidak kreatif dan lamban atau kurang kompetitif. Orientasi masyarakat pekerja Melayu Palembang memiliki pengertian yang berbeda dengan pengertian Islam yang sebenarnya. Agama bagi masyarakat Melayu Palembang dewasa ini agaknya tak lain dijadikan sebagai pusat dari pemenuhan aspek nilai-nilai secara lahiriah semata sebagaimana layaknyadahulu sebelum jaman kemerdekaan RI.. Artinya, pemahaman dan pengertian tentang fungsi dan peran agama dalam prilaku keseharian tidak terlalu terasa sebagai pembentukan dan pendorong etos kerja yang sebenarnya dari tenaga kerja Melayu Palembang. Peran agama mulai tergeserkan oleh kepentingan konsumerisme dan persaingan individualistik global.

Agama (Islam) bagi sebagian masyarakat pekerja Melayu Palembang saat ini tak lain sebagai sesuatu yang terus hidup namun bukan yang menghidupi. Kurangnya pemahaman dan pengertian yang sebenarnya tentang makna agama dalam pembentukan karakter pribadi membuat etos kerja tidak terlalu berorientasi pada proses pembentukannya. Selama ini bagi sebagian besar tenaga kerja Melayu Palembang-yang umumnya diberagama Islam, nilai-nilai Islami yang pernah diajarkan dan diturunkan oleh para orang tua dan guru, masih kurang menjadikannya sebagai landasan dan pandangan hidup yang sesungguhnya. Globalisasi pun akhirnya mampu dituding sebagai penyebab prilaku yang krisis ini.

Globalisasi sebagai agen sentral dalam proses pembawa perubahan dan pembaruan dengan semangat kapitalistiknya telah membuat tenaga kerja muda Melayu Palembang semakin gamang dalam bersikap dan menentukan langkahnya, belum lagi ditambah pada problem kurangnya pendidikan dan semangat kebangsaan yang lemah. Alhasil, strategi yang dilakukan oleh sebagian besar tenaga kerja Melayu Palembang menjadi tidak berimbas pada siapa pun.

\section{PENUTUP}

Sesungguhnya, pada kenyataannya tenaga kerja Muslim Melayu Palembang tidak pernah siap dalam memasuki dan mengarungi belantara ekonomi global. Usaha yang ada hanya terbatas pada bagaimana bertahan dengan mengandalkan semua sumber daya yang ada dan memanfaatkan sedikit kemungkinan dan sedikit peluang yang bisa diharapkan 
dari sumbangan globalisasi, tanpa ingin berniat bergrilya dan bertempur. Akibatnya yang ada, jeratan keterbatasan dan kemiskinan yang selalu dialami oleh kaum pekerja Melayu Palembang semakin membuatnya terpinggirkan dan semakin tercerabutkan dari akar budaya dan nilai-nilai Islam Melayu yang sesungguhnya.

Sejak lama, nilai kerja dalam masyarakat muslim Melayu Palembang mulai merosot akibat berkembangnya pemerintahan feodal yang zalim. Dalam sistem pemerintahan yang seperti itu, timbul kehidupan yang mewah di kalangan elite bangsawan. Pemerintahan yang otoriter menyebabkan motivasi rakyat Melayu Palembang untuk bekerja merosot.

Dalam keadaan yang lemah secara ekonomis, politis maupun mental, masyarakat Melayu Palembang tidak bisa mendukung pemerintahan. Itulah sebabnya pemerintahan Islam Melayu Palembang akhirnya lemah di dalam dan hancur oleh invansi dan akhirnya jatuh ke tangan penjajah. Runtuhnya perekonomian kaum Muslim adalah akibat penjajahan bangsa-bangsa Eropa. Mereka jatuh ke tangan penjajah karena pemerintahannya lemah. Dan pemerintahan Melayu Palembang lemah karena didukung oleh rakyat yang lemah akibat pemerintahan yang otoriter dan represif.. Koeksidensi antara kemiskinan dan kemusliman itu menimbulkan kesimpulan bahwa etos kerja di kalangan kaum muslim Melayu itu rendah.

Melayu Palembang sekarang tidak harus sama dengan Melayu lima abad yang lalu. Dalam era teknologi tinggi, manusia Melayu Palembang perlu menyadari bahwa etos Melayu Palembang harus lahir dalam era positivis dengan pilar rasionalisten pragmatis. Oleh karena itu membangun tenaga kerja muslim Melayu Palembang bukan sekedar membangun di bumi Melayu, melainkan membangun manusia-manusia Melayu, sehingga masyarakat Melayu Palembang bisa meraih kehormatan lahir batin sebagai khalifah Allah di bumi, yaitu masyarakat Melayu Palembang yang berdaya serta bisa menyelesaikan garapan tantangan hidupnya tanpa bergantung pada orang lain. Masyarakat Melayu Palembang dulunya memiliki budaya kerja yang disebut "semangat kerja" yang tinggi, semangat yang mampu mangangkat hakikat dan martabat kaumnya "untuk duduk sama rendah tegak sama tinggi" dengan masyarakat dan bangsa lain. 


\section{DAFTAR PUSTAKA}

Abdullah, Irwan. 1994. The Muslim Businessmen of Jatinom: Religius Reform and

Economic Modernization in a Javanese Town. Disertasi Ph. D. University of

Amsterdam

. 2003. "Tumbuh dan

Berkembangnya Kaum Pengusaha di Aceh".

dalam Pengantar buku Hasan Saad. Bersama Induk Semang. Yogyakarta: ReliefPress.

Abdullah, Taufik (ed.), 1988. Agama, Etos Kerja dan Perkembangan Ekonomi. Jakarta:LP3ES.

Hidayatullah", dalam Islam Reformis, Dinamika Intelektual dan Gerakan, Jakarta: Rajawali Press.

Koentowijoyo. 2001. Muslim Tanpa Mesjid: Esai-Esai Agama, Budaya, dan Politik dalam Bingkai Strukturalisme Transendental. Bandung: Mizan

Masden, Wiliam. Sejarah Sumatera. 2013. Jakarta: Penerbit Komunitas Bambu.

Moekijat. 2006. Asas-Asas Perilaku Organisasi. Bandung: CV. Mandar Maju, Bandung

Muhaimin, Yahya. 1987. “ Muslim Traders: The Stillborn Bourgeoisie". Prisma 49.

Nasution, M.A., Prof. Dr.S.Metode Research (Penelitian Ilmiah). 1992. JakartaBumi Aksara

Nawawi, Hadari, 2003. Manajemen Sumber Daya Manusia. Cetakan kelima. Yogyakarta: Gajah Mada University Press
Ndraha, Taliziduhu. 2003. Teori Budaya Organisasi. Cetakan Kedua. PT. Jakarta:Rineka Cipta

Osborn dan Plastrik. 2002. Manajemen Sumber Daya Manusia. Yogyakarta: BPFE.

Rahim, Husni. Sistem Otoritas dan Administrasi Islam. Studi Tentang Pejabat Agama Masa Kesultanan dan Kolonial di Palembang. 1998. Jakarta: Penerbit Logos.

Studi tentang Kemandirian Budaya Peluang Ekonomi dan Mobilitas", dalam Sejarah Ekonomi Modern Indonesia. Thomas Lindblad (ed.). Jakarta: LP3ES.

Prasetya, Triguno.. Manajemen Sumber Daya Manusia,2001.Jakarta: Aksara.

Usman, Gazali. Kerajaan Banjar; Sejarah Perkembangan Politik. Ekonomi Perdagangan dan Agama Islam. 1994. Banjarmasin: Lambung Mangkurat University Press

Weber, Max.. The Protestant Ethic and the Spirit of Capitalism. 1930. New York andLondon: Scribner .. "Sekte-sekte Protestan dan Semangat Kapitalisme",1982. dalam Taufik

Abdullah (ed.). Agama, Etos Kerja, dan Perkembangan Ekonomi. Jakarta:

LP3ES.

M. Loeb, Edwin. Sumatera Sejarah dan Masyarakatnya. 2013. Jakarta : Penerbit Ombak.

Musa Asy'arie Islam.Etos Kerja dan Pemberdayaan Ekonomi Ummat, Yogyakarta: Lesfi, 1997, cet. Ke1. 
156 Kontemplasi Masyarakat Muslim Melayu...

Tasmara,Toto. Etos Kerja Muslim, (akarta: Labmend, 1991, Cet. Ke-1.

Van Leur. J.C. Perdagangan dan Masyarakat Indonesia : Esai-esai Tentang Sejarah Sosial dan Ekonomi Asia. 2015. Yogyakarta : Penerbit Ombak.

Zed, Mestika,Kepialangan Politik dan Revolusi Palembang 1900-1950. 2003. Jakarta: Penerbit LP3ES.

Tenas, Efendi. 1989. Ungkapan Tradisional Melayu. Kuala Lumpur: Dewan Bahasa dan Pustaka

Dahril, Tengku.2000. Tamadun Melayu. Kuala Lumpur: Dewan Bahasa dan Pustaka

Husein, Ismail, dkk.2003. Etos Kerja DalamAcuan Budaya Melayu. Jakarta: Gema Insani Press 